\title{
She Is a Widow: The Story of Six Druze Widows in Israel
}

\author{
Janan Faraj Falah \\ Arab College for Education, Haifa, Israel \\ Email: jananf81@gmail.com
}

How to cite this paper: Falah, J.F. (2016) She Is a Widow: The Story of Six Druze Widows in Israel. Open Journal of Social Sciences, 4, 210-226.

http://dx.doi.org/10.4236/jss.2016.49018

Received: July 20, 2016

Accepted: September 24, 2016

Published: September 27, 2016

Copyright $\odot 2016$ by author and Scientific Research Publishing Inc. This work is licensed under the Creative Commons Attribution International License (CC BY 4.0).

http://creativecommons.org/licenses/by/4.0/

\begin{abstract}
This study of six Druze widows in Israel deals with Druze law, women's personal status, the widows' difficulties, and the conflicts between Druze traditional society and modernity. The Druze society is a traditional, collective, patriarchal and religious society, in which independence and the attachment to the land have always been considered central values (Amrani, 2010; Falah, 2000) [1] [2]. The women's status is considered inferior to that of the men's and their main role is conceived as raising children and taking care of the house. Following are the stories of Druze women who became civilian widows during the 1950's through the 1970's. The study examines the way widows coped with their situation in a time in which the Druze society underwent great changes, moving from a traditional society to a more modern one.
\end{abstract}

\section{Keywords}

Widows, Women Status, Druze, Society

\section{Introduction}

This research on Druze widows is significant because it is the first study dealing with this subject through personal, in-depth interviews; it explores the status of Druze women in modern society and the influence of traditional Druze laws.

The Druze religion encourages voluntary marriage in which both spouses have to fully agree to be married. In cases in which the woman wants to marry the man and her parents disagree, she can turn to the Kadi and ask him to marry them off. In addition, the Druze religion forbids monasticism among men and women.

The Druze society is a traditional conservative society which is based on rigid Eastern mentality which focuses on protecting the woman's dignity. When a woman becomes a widow, her own family and her deceased husband's family face dilemmas such as: who shall provide for the woman and her children? Who shall care and accompany her on a 
daily basis? Whether her parents or her deceased husband's parents? Is she allowed to get out of the house on her own? What would people say now that she has become the object of men's lust?

Due to these reasons, among other things, the Druze family tend to put pressure on the widow to be remarried, sometimes against her will, and sometimes to a stranger who is older than herself. In such cases, the woman is obliged to give up her children due to the fact that the Druze does not adopt children.

After the establishment of the state of Israel and the enactment of the 1957 obligatory draft law which included the Druze men, a new kind of widows has been created-the I.D.F. widows. These widows received allowance for living, which brought to a new situation of an economic independence from their families and to the refusal of many women to remarry.

Additional difficulties were created as a consequence of the modernization, which threatened the religious scholars who hurried to demonstrate their authority and power and casted bans such as: forbidding a woman to drive; forbidding religious men to take a ride in a vehicle driven by a woman; and forbidding a woman to earn a living from certain professions such as modelling, probation officer, advertisement and more.

In the present article, I shall deal with the status of the Druze widow in the past and in the modern era, while focusing on the civilian widows (whose husbands died in civilian circumstances rather than during their military service).

\section{Theoretical Background}

\subsection{Widowhood}

Loss, unfortunately, is the lot of all individuals, regardless of state, gender, age or ethnic group. The death of a spouse is an overwhelming event in an individual's life which accompanies him many years afterwards. Carnelley, Wortman, Bolger and Burke (2006) [3] found that the mourning and bereavement pursuant the death of a spouse extends over a long period of time. Even after many years, memories and talks about the deceased spouse, which cause sadness, are common. Sometimes the individual experience distress in certain dates such as the deceased remembrance-day.

Psychodynamic scholars see the loss as a process in which the individual gives up his attachment to the deceased spouse. Yet, the relation between the libido instinct remains after the spouse's death and the process of detachment (the libido energy and the emotions neutralization, without forgetting the deceased) is accelerated as time passes by. This process is known as "the loss" (Stroebe \& Schut, 2005) [3].

A current interesting approach is the use of short term therapy for dealing with loss. The pioneer of this approach was James Mann (1973) [4] who emphasized the interpersonal facet, in contrast to the classic psychoanalytical approach which defines the difficulties in Oedipal terms.

\subsection{Widows in the Arab/Druze Traditional Society}

The traditional Arab culture sees marriage as a component in the psychological and so- 
cial development of the individual (Abu-Baker, 2010) [5]. That is, an individual gets married in order to reach the maturity and responsibility stage. Such cultural perceptions intensify the view according to which events such as divorce, separation or becoming a widow, create a crisis, which, besides causing mental stress, present women as needy in many realms (Savaya \& Cohen, 2005, 2006; Abu Baker, 2010) [5].

According to Abu Baker (2010) [5], several variables are related to the widows' odds to remarry in a traditional society. A widow's chances to remarry are higher as long as she is young, her family is well off; and she has no children. Her ability to run her life independently is dependent upon her education level and her economic independence. Second marriage shall mostly take place with a spouse who is considered "inferior" in terms of age or status, and in case she refuses to remarry, she shall live under her relatives' supervision.

Abu-Baker (2002) [6] claims that the social status both of divorcees and of widows is the lowest in the Arab family hierarchy. Such women are expected to avoid sexual relationships and social "scandals", and for that end they are supervised by society. Yet, unlike the divorcees, who are blamed for their situation, the widows get some sympathy from society. According to Abu-Baker (2010) [5] a widow is supervised both by her own family and by her deceased husband's family. Such supervision causes her difficulties, and adds to her sense of loss (Abu-Baker, 2010) [5]. These claims are congruent with previous studies (for example, Al-Krenawi, 1996) [7] according to which the Druze society expects the widow to be weak, in contrast to the widower, and to experience a long term disfunction and psychosomatic distress, which symbolize the intensity of her loss and the couple relationship which has been lost. Women that do not act in accordance with this expectation, encounter explicit or implicit criticism and condemnation. Israeli-Palestinian widows experience a significant decrease in their personal wellness, lose their independence and sometimes their joy of life.

Other studies which focused on analyzing the rights and the economic, social and legal status of mothers in single-parent families in the Israeli society, showed that due to the weakening of the ideology which supported the welfare state and the intensification of the non-liberal view which undermined the foundations of the welfare state, the policy related to mothers in single-parent families was shaped and the former allowances policy, was minimized (Herbst, 2010; Toledano a \& Eliav, 2010; Shenkar-Sherk, 2010) [8]. In countries which do not bestow a generous social support and an active policy of helping working women, a large part of the mothers in single-parent families deteriorate to poverty (Svirsky, Konor-Atias \& Abu-Chala, 2008) [9]. Accordingly, the consequences of cutting the food allowances and the assurance of income in the framework of the 2003 state budget, can be seen. In the framework of that cutting, the increased rate of the assurance of income was abolished for most of the entitled individuals, including the single-parent families.

Israeli-Palestinian mothers from single-parent families encounter additional barriers which are derived from their civilian status, including: limited job opportunities, limited public transportation services, a lack of proper education frameworks, lower level 
of public services (Yonai \& Kraus, 2009) [10], few social contacts and discrimination. The later, according to Herzog (2004) [11] constitute a main factor which makes it hard for Israeli-Palestinian women to find their place in the labor market. The nationalbased discrimination on the one hand and the gender-based exclusion on the other hand, make it hard for Israeli-Palestinian mothers from single-parent families to find a job and thwart the chances of such families, in which the salary is limited to one provider, to strive to economic independence.

\subsection{The Social Characteristics of the Druze Society in Israel}

About one hundred and thirty thousand Druze live in Israel currently. The State of Israel acknowledges the separate status of the Druze as an independent society that its sons are obliged to serve in the army. The Druze are located in sixteen villages in the Carmel and the Galilee. The Druze settlements which are situated in secluded areas create a conservative united community which is characterized by a traditional life style and a patriarchal structure (Amarani, 2010) [2]. This society has always retained the religion and tradition values, among which the independence and relation to the land were central to the community (Falah, 2000) [1]. The familial relations in the Druze society are characterized by hierarchical structure in which the father has ultimate control of his extended family: his wife, single daughters, his sons, his daughters in law and their offspring. The men are located in the upper stages of the social ladder. The family members are required to obey and respect the elders in the family, and the familial ends are seen as prior to personal ones (Hassan, 1999) [12].

Women's status in the family is inferior to that of men's. Women are required to obey the men, to look modest, to avoid contact with strangers and to take care of the housework and the children. The status of the woman in the Druze society is not static, as she climbs the social ladder with her advancement in the familial life cycle. Her sons also contribute to her status because when they marry, they bring their wives into their own family unit. The sons' mother then has central pivotal role in the familial life, especially because Druze families often live in the same family compound. The woman then influences the way the young couple then raise their children. In accordance with her new higher status, the mother becomes a central figure in regard to family matters, her sons' marriage, and especially in controlling her daughters in law, their sons' wives, who are expected to obey her (Viner-Levi, 2005) [13] [14].

\section{Widows in the Druze Society}

Due to the special status of the Druze society in Israel, there are two kinds of widows: civilian widows and I.D.F. widows. This section shall be devoted to the civilian widows in the Druze society. In general, the status of the Druze widow is determined by the interface between the characteristics and customs of the society in which she lives, and the way in which her husband died. Her status is characterized by the difficulties of all Druze widows, that is, she is seen as unprotected and as prone to threats, since she lives without a man's supervision. Her obligation is double: she is committed both to her own family and to her deceased husband's family. In addition, she is hardly entitled to 
any heritage, and she is not seen as the natural custodian of her children (HershkowitzAmir, 2008) [15].

\subsection{Factors Predicting Adjustment to Life among Widows}

An Israeli study by Bar Nadav (2007) [16], examined reactions to loss which were related to the biological, psychological and social functioning of widows who became widows maximum 15 years prior to the study. The study was based on Rubin's doublecourse model (1999) The first course was related to the self-esteem and to the sense of meaning in life. In the second course the process of representing the deceased inside the widow's inner world, the widow's behaviors and feelings which were related to the memory and commemoration of the deceased, were examined. The results of the study showed that the widows encountered complex tasks. It was also found that time constitute an efficient factor which helped most of the widows. Yet, the process which the widow undergoes pursuant the death of her spouse is a spiral one, so that many years after the loss, references to the pain can be found, which proves that concepts such as rehabilitation or healing are not accurate.

Bar Nadav (2007) [16] further suggests using concepts such as process and growth, together with sensitivity and vulnerability, as concepts which shape significant experiences in the widow's life for many years. Young widows find it hard to be effective, to think and to be productive in their lives, to enjoy their life or to study. In addition, it was found that entering a second relationship is more complex and takes longer for widows than for girlfriends of deceased individuals. Widows who have children have a different experience of their loss. Being a mother to children who have lost their father, the necessity to take care of the complex everyday tasks, influence the young widow's ability to deal with her own loss, in comparison to widows who do not have children. Another result was that women who did not experience a loss of a spouse reported on greater satisfaction of live and found more meaning in life in comparison with widows. They also reported better functioning related to many aspects of everyday life. Their thoughts regarding their spouse were more calm and pleasant. Loss has a long term effect on widows, affecting their lives for many years, whether they are involved in a new relationship or not (Bar Nadav, 2007) [16].

The literature which examined the predicting factors for widows' adjustment to life after their husbands' death points to personal, interpersonal and situational factors (Bar Tur, 2005; Bar Nadav, 2007 [16]; Derman, 1999) [17].

\subsubsection{Personal Factors}

Four personal factors which predict widows' adjustment to life were found:

1) Emotionally stable individuals deal better with stress such as losing a spouse; 2) the feminine adjustment style of looking for emotional support and social contacts is more effective than the masculine one, which includes investment of energy in the workplace; 3) no difference was found between man and women in their psychological reactions to a spouse death, yet it was found that the mourning process affects more the physical wellness of men than that of women; 4) younger widows who are 20 years old 
or less react with greater emotional intensity to their spouse loss than older women, that is, loss has a stronger impact on the emotional stress and adjustment process of the younger widow (Bar-Tur, 2005; Bar Nadav, 2007] [16]; Derman, 1999) [17].

1) Interpersonal factors-the social networks of I.D.F. widows

Close and supportive relationships help the individual deal with stress. Bankoff (1983) [18] emphasized the effectiveness of the social support in the process of adjusting to loss. Amir (1979 [19]) showed that the social fabric around widows played a significant part in their adjustment. In addition, their social adjustment, rather than their basic personal characteristics, was the best predictor for their general adjustment.

One of the roles of a "social network" (Shamgar-Hendelman, 1990) [20] is to supply the family the practical, social and normative knowledge which it requires. The status of the family in the social network helps the family to achieve an independent identity, to measure its achievements, and to identify its relative status within the community. Shamgar-Hendelman [20] used a sample of I.D.F. widows in order to examine how the change in the family composition affects its place in the social network. It was found that the structure and the functioning of social networks of individuals who lost a partner are fundamentally different from those which existed before the familial change. The change affected not only the spouse, but rather the whole family: parent and children. When the widow is willing to fulfil the role she used to fulfil in the different social networks before the crisis, she frequently finds out that her place in those networks has not been kept for her. The social networks which were examined were relatives, friends and colleagues. Although the change process in each of the widow's social networks has found its expression differently, all showed the same trend, that of a decrease of the network, a fact which marginalized the widow's familial unit, and made it lose its power and prestige inside that network.

Two main factors were found to influence the relationship between the widow and her parents. The first factor was the overall perceptions regarding the mutual rights and obligations of parents and their daughter, who became a widow. Those perceptions are found on a continuum while at the one end there is the perception that upon her marriage, the daughter loses her rights to rely on her parents, even after her husband's death, and, at the other end of the continuum, the perception that a daughter who became a widow returns to her status before marriage. Such perceptions can be found with the parents and the daughters, yet, sometimes they are not compatible. The second factor which influenced the relationship between the widow and her parents

The routine and the familiar behavior patterns reverted to what they were in the past and the widow regained the role she used to have before her marriage.

Shamgar-Hendelman [20] also relates to the widow's relationship with her brothers. in case of a conflict of the widow with her parents, her brothers tend to take their parents' side, and, they are sent to present the interests of the family to the widow. According to Lopata (1973) [21], after the parents' death, the relationships between the widow and her brothers are shaped anew, become more relaxed and based on greater permissibility, mutual respect to privacy and open negotiation regarding mutual ex- 
pectations.

In regard to social networks, it was found that the I.D.F. widows encountered a new reality. They were no longer invited to participate in social events of their deceased husband's colleagues. Widows have found out that they were allowed to participate in such events only partially, that their place in the group was marginalized, and that their place was kept for them only by their most intimate friends. A kind of censorship has been created in the group, which determined which events were suitable for widows and which were not. Accordingly, they were invited only to those which were considered appropriate for them. In regard to friendships and close friends, a process of impoverishment of the widow's friends network was documented, which turned the network into a unisex network, since only seldom the husband's friends kept in touch with the widow. Yet, her relationships with her friends continued as usual and sometimes even became closer. In general, it can be seen that the transition in the non-formal interpersonal relationships left the widow with a limited social network which included mostly women, its scope of action was diminished and men were only remotely related to it (Shamgar-Hendelman, 1990) [20] [The deceased, the missing unit, breaks off the balance in the family. Shamgar-Hendelman (1990) [20] states that the influence of the missing unit on breaking off the balance in the other social networks is no less devastative. In a study made by Vekstein (1987) [22] which compared married women to I.D.F. widows it was found that married women perceived the social assistance they were given by the social networks as supportive, in comparison with the other widows. In addition, it was found that the levels of guilt, lack of hope, psychosomatic symptoms and depression among I.D.F. widows were higher than those of married women. In addition, widows tend to see the upbringing of children as more central role in a woman's life, in comparison with married women. Another result was that the more open the widow was to the outer world, including nurturing and being pedantic regarding her appearance, keeping social contacts and relationships with potential spouses, her adjustment was better and she reported less grief and lack of hope. Through maintaining social relationships and by using social help, the I.D.F. widows deal better with their depression and their sorrow.

2) Situational factors and children upbringing

The situational factors which were found as predicting a widow's adjustment to life were: the nature of relationship with the spouse; expected or unexpected death; the burden that the deceased cast upon her; responsibilities and children upbringing.

The nature of relationship with the spouse-it was found that the more intimate were the relationship of the married couple-the harder was the widow's loss experience. Close marriage relationship usually leaves greater emptiness which is hard to fill.

Expected or unexpected death-it was found that sudden death was experienced more traumatically than expected one. In case of a sudden death, a strong sense of loss of control aroused, as well as loss of trust and a strong feeling of guilt, due to the inability to bring an end to unfinished issues. In addition, She has found that after a sudden death, the rate of emotional disturbances found among widows, such as anxiety and 
depression was higher, and that level remained high for two or three years after the event that the sudden death does not enable an "anticipatory grief" which allows a gradual process of parting from the deceased and which constitutes an important factor in a successful adjustment process. In contrast, in case of an expected death, the idea of death is dealt with gradually.

\subsubsection{The Effect of the Religious Scholars on the Woman and Her Position}

The Druze woman is preferable to the man in the process of joining the religious cohort (Aukal). The rate of religious women among the Aukal is higher than that of men's. Yet, in spite of the fact that the women outnumber the men, the men have greater influence, while the women's influence is almost inexistent. All rules and regulations are legislated by men. Men can also cast embargo. The application to join the religious circles (Talab al-Din) is addressed to men. In addition, the removal from the place of worship due to certain offences

Women are removed due to offences such as: participating in a wedding with songs and music; riding a car by the daughter or by the daughter in law; riding a car driven by a woman. For such offences women are removed from the place of worship for two to six months. In order to rejoin the prayer circles, the woman has to fill an application again. The application is addressed to the Sheikh, that is, to the religious scholars rather than to the religious women and in case the Sheikh himself broke the (unwritten) set of rules, he removes himself. Some are being removed since they allowed their daughters to study in mixed schools (which were more common in the past). In addition, in villages which didn't have schools, parents were not allowed to send the girls to study outside the village). The scope of such prohibitions in the villages was relative to the number of religious scholars and their attachment to the religious management which situated in Julis village - the village of the spiritual leader of the Druze society.

Such restrictions blocked the Druze woman from reaching the higher education institutions which were situated outside the Druze villages, yet, many parents allowed their daughters to continue their studies. That created a conflict between the religious scholars and the parents, which led to embargo and exclusion. Yet, such steps were not successful and a certain balance was maintained between the religious and secular groups, while hindering women's progress, yet not preventing it (Faraj-Falah, 2005) [23].

According to the above results, the woman's status can be summarized as follows:

In spite of the fact that the religious women rate is higher than the men's (from different reasons: some of the men work outside the village in different jobs and some are employed in the security forces and come home every weekend or a fortnight, in comparison with their wives who are mostly housewives or work in the village), yet when a single daughter to religious parents drive a car, the application to join the religious circles is left to the Sheikhs, the men, and they decide whether to accept or reject it; Men set the internal rules; They cast embargo (mukataa) on religious individuals who break the rules; and they can decide to accept him back; Men rather than women read aloud during the prayer, even if the women are literate, or are better educated than the men; 
Exclusion from religion (that is from the religious group and the option of praying with them in the Halwa) is made for a limited period of time (from two weeks to six months). Some of the behaviors which bring exclusion are: In some of the villages, the daughter in law that is, the son's wife, and in certain places, in case of taking a ride with a woman driver; when the single girls participate in social events which include music and dancing (this doesn't apply to married women, who are under the responsibility of their husband and his family).

In the past, those who studied in a mixed school or a school situated outside the village. Even today, there are families which do not allow their daughters to study in higher education institutions which are situated outside the village.

All these norms are not written norms, which are dependent upon place and time.

According to religion, the man and the woman are equal in terms of expected behaviors, yet, the sanctions do not relate to men who drive, study in mixed schools, or participate in social events with music and dancing. The sanctions are designated for women in a patriarchal society in which the freedom of women threatens the status of men. In addition, the influence of the Arab-tribal-Eastern-desert society is very strong. For example, the Druze forbid murder, yet, in practice, murders take place when a woman (but not a man) is blamed with adultery (a man is only punished by being denied entrance to the religious circles) (Faraj-Falah, 2005) [23].

The influence of the religious scholars is very strong due to several reasons. The main reason is that religion is confidential, so one cannot doubt it. In some cases although the religious individuals are illiterate, they set rules according to their own discretion, which are sometimes incompatible with the Druze religion. As aforementioned, the influence of the religious scholars is very strong and it hinders the advancement of the Druze women in Israel, in comparison with other societies (in spite of the fact that religion itself does not discriminate between men and women). One of the great scholars of the Druze religious laws is $\mathrm{Al}$ Amir Al-Said whose influence on the Druze law and the Druze women is apparent.

1) $\mathrm{Al}$ amir Al-Said

The Druze, like any other religious group, have Holy Scriptures and religious laws written by religious scholars. The religious laws bridge between the Holy Scriptures and the everyday necessities and existence, while relating to all life aspects.

The most salient scholar among the Druze scholars is the Amir Abd-el-Alla AlTnuchi who was born in Abbayah, Syria (1407-1479) (Noyhad, 1975) [24]. Al-Tnuchi wondered from village to village in order to study. He wrote many essays and several books on topics such as: the interpretation of faith, the regulations, the law directives; living a proper life in accordance with the spirit of religion (for example, his book on the marriage and divorce of monotheistic believers).

Al-Said stresses the importance of marriage as a basic tenet of faith since it is based on equality and justice. More than 500 years ago, he encouraged marriage and forbade monasticism as well as called for equality between men and women. He demanded equality in religion; for example, according to his interpretations, a woman can refuse 
marital proposals and her parents cannot force her into marriage; a married woman can request divorce; and, finally, there is no polygamy in the Druze religion.

In addition, Al-Said stressed that men should teach their wives to worship God and to read and write, in cases the women are illiterate. In case a husband is not able to do it himself, he should take her to a proper teacher (Al-Tanuchi abd-Alla: Tashree zawaj al mowahdeen walmowahedat) [25].

2) Inheritances and wills

Wills have a special place among the Druze. They take the place of the inheritance in the Islam. There is absolute freedom regarding the distribution of property after death, in contrast to the customs of the Islam. In case an individual has passed away and did not leave a will, his property shall be divided equally between his children. It should be noted that according to religion, girls are entitled for inheritance, yet, as in practice among the non-Jewish societies in Israel, girls do not inherit.

In order to refer to the status of the Druze widows, several issues related to religion have been stressed. For instance, the Druze religion encouraged marriage and even second marriage and allowed inheritance by daughters.

\subsubsection{The Druze Widow in the Past}

According to the Druze religion, men and women are equal in terms of their duties. Yet, in a patriarchal society, the freedom of women threatens the status of men, so men tend to limit it. In addition, the demography in the Druze society played a significant part: Druze live in Israel in 18 hilly villages. In these villages there aren't any higher education institutions. In the past, in many of them, there weren't any high schools neither, a fact which made it difficult for girls from traditional families to study in a higher education (Faraj-Falah, 2004) [26].

In addition, the influence of the Arab-tribal-Eastern-desert society is very strong. The attitude of the Eastern society toward the widow and the widower is not so favorable. The fear from the society and the relatives made the family worry and so the widow was married off to the first man who came her way, without any consideration of his age, his economic or social status, as long as he discharges them of their responsibility to their daughter or sister who became a widow. In many cases the children were handed to the father's parents or one of his brothers, even when the mother did not approve.

\section{Methodology}

\subsection{The Array of the Study}

The present study makes use of the narrative approach which deals with stories, in contrast too other qualitative-interpretive study arrays (Pinnegar \& Dayness, 2007) [27]. The narrative paradigm is one of the paradigms included in qualitative studies which are based on the interpretive and naturalistic approach which wishes to expose the meanings individuals attach to phenomena in the world (Denzin \& Lincoln, 2005) [28]. The qualitative-interpretive studies have a shared conceptual and methodological foun- 
dation, yet they are not identical. Denzin and Lincoln (2005) [28] identify interpretive paradigms which are included under the "family" of the qualitative studies: constructivist, feminist, ethnic, Marxist/critical, participative, cultural studies (Denzin \& Lincoln, 2005 [28]; Guba \& Lincoln, 2005) [29]. Accordingly, such paradigm is suitable for the present study in order to examine the life stories of Druze widows.

\subsection{The Participants}

Six widows participated in the present study (three became widows in the 50ties and 60 ties and three others in the 70ties and 80ties), from four Druze villages. I chose widows who were remarried due to poverty and inability to provide for their children. Some of the widows were forced to marry their brother in law (their deceased husband's brother) in order to maintain the allowance and the dependents' pension given by the National Insurance Institution. The present sample has been chosen according to the purposive sampling which, in Miles and Huberman's terms (1994) [30] samples "politically important cases". Such sampling is based on the assumption that "in every social structure there are different individuals in a different ratio to the general social structure" (1994:28)

\subsection{The Tools}

The narrative methodology focuses on stories as data. Since the social reality is a narrative reality and we understand and know it through stories, stories are therefore seen as the proper tool to examine the human reality. Narrative study tools are written and spoken stories, personal and group stories, life stories and self-narratives. Most of these stories are based on words (Riessman, 2008) [31]. I chose this tool in order to emphasize the life course of the Druze widow after the death of her husband. The stories I have collected during the study were all told by the participants.

\subsection{Data Analysis}

The data analysis is based on the realization that the story itself creates meaning, and serves for understanding and organizing events. In that sense, on the one hand, the narrative describes reality, and on the other hand, it shapes it and gives it meaning (Lieblich et al., 1998) [32]. The story is a model of the world, and its ability to serve as a tool for restructuring of the world is based on its unique characteristics such as: arranging the events sequentially, maintaining causal relationships between events, creating a plot and twisting it, and a personal description of the main character, his inner world and his consciousness.

Thousands of events are part of our life's chronicle and shall never be presented as part of the narrative, while others shall become part of our personal narrative. The distinction between them, according to Bruner (1990) [33] is related to the degree in which they break the routine and the regular order. The events which "break" the expected sequence, which deviate from the norm, are those which are worth telling, which are woven into the narrative we tell about ourselves-to ourselves as well as to others. 
Thus, a part of the meaning of every narrative is derived from the gap between "what was expected to happen" and "what actually happened" (Bruner, 1994) [33]. In the present study in every narrative I have focused on the sequence of events, their connection and the inner worlds of the participants.

\section{The Results}

Following are the stories of Druze women who became widows during the Fifties and Sixties of the twentieth century as shown in Table 1:

1) Fatma-a young woman from a Druze village in the North of Israel. Her husband has passed away when she was in her twenties and left her with two sons and one daughter. Camel, the deceased, was a poor man. After their marriage, they lived with his mother, his sister and his younger brother and didn't build a home of their own. Two weeks after his death, Fatmas' father took her and her children to his home. After less than six months, an invalid one-legged man, asked her father to marry her and her father has agreed unconditionally. The new groom didn't want to keep her children.

2) When Rafika's husband was murdered, she was pregnant with their forth son. Two years after she gave birth to that child, Mahmud from the next village asked her father to marry her and her father agreed. Along with Fatma, Rafika was also forced to leave her four children. The groom was a widower and had seven children, two of them were at Rafika's age. She gave birth to five children in her second marriage and her husband has passed away after eight years.

3) Yusra's story is especially tragic since she became a widow three times. She had children from each of her husbands and after the death of her third husband, she has returned to her parents' home, and was separated from all her children.

In all three cases the widows were not asked to their wishes regarding the second marriage or the specific groom; the widows were not able to state their opinion regarding whether to go on living in her husband's home with his family and to raise their children; the widows' children lived as orphans from both parents (their father has passed away and their mother were forced to leave them); poverty and disability of the

Table 1. Data on the widows that posts in the research.

\begin{tabular}{|c|c|c|c|c|c|c|}
\hline & Remarried & $\begin{array}{l}\text { No. of } \\
\text { children } \\
\text { In the first } \\
\text { marriage }\end{array}$ & $\begin{array}{l}\text { No. of } \\
\text { children in the } \\
2 \text { marriage }\end{array}$ & $\begin{array}{l}\text { Description of } \\
\text { the } 2 \text { groom }\end{array}$ & $\begin{array}{c}\text { Leave her first } \\
\text { husband } \\
\text { home }\end{array}$ & $\begin{array}{c}\text { No. of } \\
\text { marriages }\end{array}$ \\
\hline Fatma & yes & 3 & & $\begin{array}{c}\text { Disabled } \\
\text { without one leg }\end{array}$ & yes & 2 \\
\hline Rafiqa & yes & 4 & 7 & Old man & yes & 2 \\
\hline Yusra & yes & & $\begin{array}{c}\text { Isn't } \\
\text { mentioned }\end{array}$ & 3 husbands & yes & 3 \\
\hline Suhad & yes & 2 & ------ & Brother in law & no & 2 \\
\hline Suzan & no & 1 & ----- & ------ & ------ & ----- \\
\hline Nagua & no & 3 & - ------. & ----- & no & 1 \\
\hline
\end{tabular}


husband's family or the widow's parents to bear the financial burden; their lives were influenced by fear and shame ("what would people say").

Following are the stories of Druze women who became widows during the 1970's and 1980 's who were forced to marry their brother in law in order to maintain their widowhood allowance and the dependents pension from the Social Security:

4) Suhad-a mother of two babies. Her husband was killed in a car accident. She lived in the beautiful house her husband had built. On the funeral day, the women whispered that her brother in law, Salem, has to marry her since he is single and in the right age. After the mourning period (in the Druze society after the next holiday or one year from the date of death), they got married. After a short period of time, Salem became envy of his deceased brother, took his picture off the wall and began to hit his wife and her daughters. Suhad requested a divorce. Her father in law supported her on the condition that she would not remarry and would live in her own house with her daughters. She learned sewing, started to work in a sewing workshop and lived a dignified life, supporting herself.

5) Sausan's story is different. She was twenty years old, a mother of a five months old baby when her husband had committed suicide in the private orchard of the family. No one knew the reason for his suicide. The family went through a very difficult time since the Druze society forbids praying for an individual who has committed suicide.

Sausan has decided to take her little boy and return to her parents' home, claiming that the house she lived in was adjacent to her brother in law's home, which was full of young guys and so as a young widow it was not appropriate that she would stay there. Her husband's parents tried to convince her to stay in their home and the mother was willing to stay with her at nights, so that she would not be left alone. Sausan refused, yet she agreed to give up, on the condition that one of her young brother in law (who was engaged to a girl he dearly loved) would marry her. The husband's family agreed, but the guy refused and left the house. The pressure of the family almost pushed him to commit suicide. The distinguished men of the society tried to interfere, yet, the problem has not been solved yet.

6) Nagua, a young woman married a rich doctor who lived in one of the nearby cities to her village. He built her a big and beautiful villa in the city. After years, he passed due to a malignant disease, leaving a thirty five year old woman and three children. Already in the funeral Nagua's family and her husband's family asked her to come back to the village. In the village she didn't have a house, yet she had a land. Nagua refused and insisted on staying in her own house. Finally, the ostracism attempts on behalf of both families have failed and she still lives in the city with her children, and of course, has not been remarried.

In all three stories the allowance and the social security which the widows were entitled to, contributed to the fact that some of the women refused to remarry and continued to live with their children; in some of the cases the widows were very young, with one or two babies. In such cases they were forced to marry their brother in law (their deceased husband's brother). The widows found it hard emotionally and functionally to adjust to the change in role from a brother in law to a husband. In all these 
stories the wish of the husband's family to keep the bride in the family and prevent her from marrying a stranger, is apparent. It should be noted that since it is uncustomary among the Druze for a stranger to live on the estate of another family, the children's houses are usually built on lands which are still registered in the land registry on the name of their grand-grandfather.

\section{Discussion}

In this part of the paper I would present a discussion of the results, with reference to the literature and a personal note. The present study examined Druze civilian widows who became widows in the 70ties and on. The Druze society is a traditional, collective, patriarchal traditional and religious society, in which independence and the attachment to the land have always been considered central values (Amrani, 2010; Falah, 2000) [1] [2]. The women's status is considered inferior to that of the men's and their main role is conceived as upbringing children and taking care of the house (Viner-Levi, 2005) [13] [14]. The Druze widow's status is derived from the interface between the characteristics and the customs of the society in which she lives, as well as from the way her husband found his death. So, on the one hand, her widowhood is characterized by difficulties which are common to all widows, because she is seen as defenseless and a target for thereat (living without the supervision of a man). She is seen as committed both to her own family and to her husband's. In addition, her rights in the inheritance are limited and she is not seen as the natural guard of her children (Hershkowitz-Amir, 2008) [15].

Religion has a dominant effect on the life of the Druze woman in general and of the Druze widows in particular. The Druze widow is considered to be the weak link of society and suffers from accusations that she acts against the religion scholars' advice (Faraj-Falah, 2004) [26]. It is easy for men to put pressure on women especially religion sanctions and religious exclusion so that other women shall see and learn. All these alleviate the men's status and lowers that of the women. In spite of the fact that the Druze religion treats men and women as equal, in practice, such equality does not exist, probably due to Arab and Islamic customs as well as to the Koran laws regarding women. For instance, women are entitled for an equal inheritance to that of men, yet, the reality is different since it is influenced by the Islamic old customs. It should be noted that the Druze religion encourages second marriage and allows inheritance by women ( $F a-$ raj-Falah, 2005) [23].

The present study wished to examine the development of the Druze widow's status and her constitutional rights. The narratives of the Druze women who became widows in the 50ties and 60ties of the previous century (Fatma and Yusra) showed that they were immediately remarried off by their parents, sometimes against their will. This result supports the perception that the status of the Druze woman is that of a dependent member of society, both socially and economically. This status prevents her from expressing her opinion or taking steps against her parents. The second marriage is very common, yet, due to the poverty of the families and the unemployment of the Druze 
women who are mostly housewives, the woman's parents preferred not to raise her children, but rather to give them away to the deceased son's parents (Faraj-Falah, 2005) [23].

Regarding the interpersonal factors, the second marriage removes the woman away from her deceased husband's family, while she moves to her new husband's family. In regard to situational factors and child upbringing, they are non-relevant in our case, since in all three cases the children were taken away from their mother.

It seems that in the 50ties and 60ties the widows' fate was related to variables such as the economic status of the family, the widow's age, her attachment to her deceased husband. It also seems that widows could not control their fate, which was determined according to social customs, especially according to the belief that aggressive interference with the widow's life shall help them in the long run to deal with her loss.

In regard to the other three stories, Suhad, who married her brother in law, suffered from domestic violence and finally got divorced on the condition that she shall stay with her daughters and shall not marry again; Suasen, whose husband committed suicide, went back with her daughter to her parents' house and agreed to return to her deceased husband's house on the condition that she shall marry one of her brothers in law; and Nagua, whose after her husband's death, stayed in the city and did not return to the village in spite of the pressures put on her by the two families.

According to these three stories it seems that the better the economic status of the widow and the less she is dependent upon others, she is better able to take control of her life and even oppose her family and her deceased husband's family.

When considering the factors which influence the way the widows deal with their loss, only situational factors and child upbringing influence the decision regarding the widow's future. As aforesaid, the economic status is considered, so that well off widows with children, are not forced to remarry due to financial reasons. Yet, when a widow is not well off and doesn't have any children, she returns to her parents' home, and gets no share in the inheritance.

The literature review shows that when a Druze widow is dependent on others financially, her fate is determined by her parents, a fate which adds difficulties to the primary misfortune of her husband's death. In contrast, when a widow gets an allowance and has a stronger economic background, she is able to determine her fate, in spite of the families' pressures.

\section{Summary}

In sum, the attitude toward the widow in the Druze society is influenced by the wish to keep the widow, her children and her deceased husband's property together. The social pressures and the fear from gossip and from damaging the widow's reputation (which damages the reputation of her family and her deceased husband's family) play a significant part in her future. Some widows are able to withstand societal pressures; they choose not to wear traditional long dresses and head coverings, and prefer to wear fashionable clothes. Instead of staying home as if in mourning, they choose to travel and 
participate in community events.

The present study has several limitations, including the small number of cases and the fact that the study has been done many years after the death of the husbands, when the widow has long been remarried. Future studies should include a larger number of participants, as well as women who became widows only lately, in order to examine their coping with their situation in a time in which the Druze society goes under great changes from a traditional society to a modern one. Further studies should also examine the coping of the I.D.F. Druze widows (whose current number amounts to about 200), especially in light of the new law which enables the I.D.F. widows to receive their allowance from the Ministry of Defense even after they remarry.

\section{References}

[1] Falah, S. (2000) Druze in the Middle East. Ministry of Defense Publishing.

[2] Amarani, S. (2010) The Druze between Congregation Nation \& State. Heikin Kathedra of Geo-Estrategy, Haifa University.

[3] Carnelley, K.B., Wortman, C.B., Bolger, N. and Burke, C.T. The Time Course of Grief Reactions to.

[4] Mann, J. (1973) Time Limited Psychotherapy. Harvard University, London.

[5] Abu-Bakar, H. (2010) Between Independence \& Dominance: The Case of the Arab Widow. In: Abu-Rabia-Quide, C. and Winner-Levi, N., Eds., Palestinian Women in Israel: Identity Power-Relations \& Coping, Van Institute Lir \& Hakibutz Hameuhad, Jerusalem, 27-48.

[6] Abu-Baker, K. (2002) Career Women or Working Women? Change versus Stability for Young Palestinian Women in Israel. The Journal of Israeli History, 21, 85-109. http://dx.doi.org/10.1080/13531040212331295872

[7] Al-Krenawi, A. (1996) Groupwork with Bedouin Widows of the Negev in Medical Clinic. Affilia, 11, 303-318. http://dx.doi.org/10.1177/088610999601100303

[8] Toledano, E. and Eliav, T. (2010) Single Parent Families 1992-2010. National Insurance Institute of Israel the Planning Department, Jerusalem. http://www.btl.gov.il/Publications/survey/Documents/seker_232.pdf

[9] Svirski, S., Konor-Atias, A. and Abu-Chalah, H. (2008) Social Current Situation 1998-2008. Adva Center. http://www.adva.org/default.asp?pageid=1001\&itmid=524\#

[10] Yonai, Y. and Krauss, V. (2009) Cultural or a Pattern for Opportunity: Why Do the Majority of Palestinian Women Not Working? In: Azaiza, P. and Abu-Bakar, H., Eds., Arab Women in Israel-Present \& Future State, TLV, Ramot, 227-258.

[11] Herzog, H. (2004) Both an Arab and a Woman: Gendered, Racialised Experiences of Female Palestinian Citizen of Israel. Social Identities, 10, 53-81. http://dx.doi.org/10.1080/1350463042000190994

[12] Hassan, M. (1999) The Politics of Honor: Patriarchy, the State \& Honor Killing of Women. In: Izraeli, D. and Fridman, A., Eds., Sex, Gender \& Politics, Hakibutz Hameuhad Publications, Tel-Aviv, 267-305.

[13] Viner Levi, N. (2005) Call Me Um El Futah: Higher Education as a Cultural Encounter. An Assay in a Set of Articles, David Yalin Publications.

[14] Levi, N. (2005) Higher Education as an Encounter of Culture, Society \& Attitudes. Changes in Pioneer Druze Women. Social Issues in Israel, a Social Paper, 5-30.

[15] Hershkowitz-Amir, A. (2008) My Husband Died-Is This the End of the World? The De- 
veloping Forces of the Druze IDF Widows. Seminar Paper in Sociology \& Anthropology, University of Tel-Aviv.

[16] Bar Nadav, O. (2007) Spousal Loss and the Two Track Model of Bereavement: Longitudinal effect of Bereavement on Young Women. Submitted in Partial Fulfillment of PhD by Publication Requirements.

[17] Derman, D.S. (1999) Grief and Attachment in Young Widowhood. Temple University, Philadelphia.

[18] Bankoff, E.A. (1983) Social Support and Adaptation to Widowhood. Journal of Marriage and the Family, 45, 827-839. http://dx.doi.org/10.2307/351795

[19] Amir, Y. (1979) Factors of Adjustment of IDF Widows. Megamot, 25, 119-130.

[20] Shamgar-Hendelman, L. (1990) War Widows Web-Sites. In: Bar-Yosef, R., Ed., A Slave, Integration, Work, The Hebrew University, Jerusalem.

[21] Lopata, H.Z. (1973) Self-Identity in Marriage and Widowhood. Sociological Quarterly, 14, 407-418. http://dx.doi.org/10.1111/j.1533-8525.1973.tb00869.x

[22] Vekstein, H. (1987) Meditative Factors in Adjustment Processes. Seminar Paper, Haifa University, Haifa.

[23] Faraj-Falah, J. (2005) The Druze Woman. Barkai Publications, Rishon LeZion.

[24] Noyhad, A. (1975) Seerat El-Amir Gmal A-Din AbDalla El-Tanuchi. Beirut Publication.

[25] Al-Tanuchi (1988) Canon Tashria Zuhaj ElMuhadin W ElMohadath W Talcohm, El Maktaba El MaArofa, Lebanon.

[26] Faraj-Falah, J.(2004) The Youth Attitude Towards the Status of the Druze Woman in Society. 163-179.

[27] Pinnegar, S. and Daynes, J.G. (2007) Locating Narrative Inquiry Historically. In: Clandinin, D.J., Ed., Handbook of Narrative Inquiry. Mapping a Methodology, Sage Publications, Thousand Oaks, 3-34. http://dx.doi.org/10.4135/9781452226552.n1

[28] Denzin, N.K. and Lincoln, Y.S. (2005) Introduction: The Discipline and Practice of Qualitative Research. In: Denzin, N.K. and Lincoln, Y. S., Eds., Handbook of Qualitative Research, 3rd Edition, Sage, Thousand Oaks, 1-32.

[29] Guba, E.G. and Lincoln, Y.S. (2005) Paradigmatic Controversies, Contradictions, and Emerging Confluences. In: Denzin, N.K. and Lincoln, Y.S., Eds., The Sage Handbook of Qualitative Research, 3rd Edition, Sage, Thousand Oaks, 191-215.

[30] Miles, M.B. and Huberman, A.M. (1994) Qualitative Data Analysis: An Expanded Sourcebook. Sage, Thousand Oaks.

[31] Riessman, C.K. (2008) Narrative Methods for the Human Sciences. Sage, Thousand Oaks.

[32] Lieblich, A., Tuval-Mashiach, R. and Zilber, T. (1998) Narrative Research: Reading, Analysis, and Interpretation. Vol. 47, Sage, Thousand Oaks.

http://dx.doi.org/10.4135/9781412985253

[33] Bruner, J. (1994) The Remembered Self. In: Neisser, U. and Fivush, R., Eds., The Remembering Self, Cambridge University Press, Cambridge, 41-54.

http://dx.doi.org/10.1017/cbo9780511752858.005 
Submit or recommend next manuscript to SCIRP and we will provide best service for you:

Accepting pre-submission inquiries through Email, Facebook, LinkedIn, Twitter, etc. A wide selection of journals (inclusive of 9 subjects, more than 200 journals)

Providing 24-hour high-quality service

User-friendly online submission system

Fair and swift peer-review system

Efficient typesetting and proofreading procedure

Display of the result of downloads and visits, as well as the number of cited articles

Maximum dissemination of your research work

Submit your manuscript at: http://papersubmission.scirp.org/

Or contact jss@scirp.org 